\title{
Professionalization and Exclusion in ESL Teaching
}

Sherry Breshears

\begin{abstract}
As ESL/EFL teachers, how do we fit into the spectrum between unskilled workers and highly trained professionals? This article examines three features of the traditional professions and applies them to the ESL/EFL context. It considers problems with the lack of mandatory standardized certification, critically assesses attachment to the university, and examines the role of the professional organization in raising the status of the occupation. The article concludes by calling for further empirical inquiry into the working conditions of English-language teachers. In this way, we will be able to make informed choices about the direction our profession should take.
\end{abstract}

En tant qu'enseignants $A L S / A L P$, où nous situons-nous sur le spectre entre les travailleurs non spécialisés et les professionnels hautement qualifiés? L'auteure étudie trois caractéristiques des professions établies et les applique au contexte ALS/ALP. Elle évoque des problèmes résultant du manque d'accréditation normalisée obligatoire, présente une évaluation critique d'un lien avec l'université et étudie le rôle que joue l'organisation professionnelle dans le rehaussement $d u$ statut du métier. L'auteure termine en proposant que la recherche empirique sur les conditions de travail des enseignants d'anglais se poursuive pour que l'on soit en mesure de faire des choix éclairés quant à la direction que devrait adopter notre profession.

Introduction: The Lowest of the Low

What makes a professional?

I recently attended a conference presentation on problems with professionalism in ESL. After the presenter was finished, members of the audience exchanged views about issues in status and working conditions for teachers. I brought up the fact that I worked in the private language-teaching industry in Vancouver and that I felt there were issues unique to our group, that our working conditions were even more problematic than those in some other types of institutions. The presenter responded jokingly, "Oh yes, the lowest of the low."

The lowest of the low. Surprisingly, I was not offended by this. In fact, it gave me a certain relief to know that someone else recognized the circumstances under which I work. We had been discussing the marginalization of ESL teachers among other teaching communities, and it suddenly 
became clear to me that I was working on the periphery of an already marginalized profession.

Am I a professional? Do I count? In seeking to understand the nature of this question, I conducted a focus group with three teachers working in private ESL schools in Vancouver. I wanted to hear about their perceptions of their work. After a long group discussion about the conditions of our work, I asked, "Are we professionals?" It was a difficult question to answer, given the discussion we had just had about the treatment we receive in our workplaces. One answer, however, stands out in my mind as particularly telling: "Am I a professional? No, I'm not a professional. I'm not treated as a professional. I don't even have a desk." Is what makes a professional, then, a desk? It seems as good a place as any to start.

It is interesting that the desk was chosen by this instructor as a sign that one had reached a certain stage in one's career. It represents the material comforts that reward social standing. A survey of the literature on the professional status of ESL teachers reveals that, unfortunately, our group lacks the social standing granted to many other professions. This has been documented for well over a decade in the literature on ESL and $\mathrm{EFL}^{1}$ teaching (Auerbach, 1991; Blaber \& Tobash, 1989; Brown, 1992; Edstam, 2001; Pennington, 1991; Freeman, 1992; Wright, 1988). More recently, researchers have begun looking empirically at concerns teachers have about the working conditions that influence their performance in the classroom (Crookes \& Arakaki, 1999; Johnston, 1997; Pennington, 1991; Yeager-Woodhouse, 2003). I intend to challenge the assumption that professionalism is primarily the responsibility of the teacher, a notion implicit in many movements toward professionalism (see, e.g., Edstam, 2001). The few studies that have examined the teaching conditions of workers in ESL suggest that factors outside the control of the teacher contribute to lower levels of performance.

In the following discussion, I examine some differences between professionalism and professionalization and propose that a distinction between them can help us in understanding constraints on teacher performance. After showing that professionalism is contingent on professionalization and improved working conditions, I look at structures available to ESL teachers to support this process. Two structures in particular, the university and the professional association, have historically aided groups in distinguishing themselves as worthy of the status and remuneration associated with particular kinds of work.

Universities, I argue, have historically emphasized a rational, sciencebased approach to learning and, therefore, have not placed great value on the types of knowledge produced in the area of education. In addition, the unequal access to knowledge promoted by the university raises concerns as to whether our profession is well served by this institution. I also consider the responsibilities of professional organizations representing teachers of 
ESL. As a group, we need to decide between two potential roles for the professional organization: the setting of standards and advocacy. In view of a discussion on power and discourse in academia, I also intend to question the structure of power and knowledge in our professional organizations, about who speaks, and about how we can arrange ourselves to be more inclusive of all members of the occupation.

This article attempts to address a broad range of practitioners' experiences. It will be of particular interest to those teaching in the private sector or the public college. In general, however, I hope to encourage discussion about the role of TESL Canada, as well as the provincial and territorial affiliations, and about how it might best serve the population it strives to represent.

\section{Professionalization and Knowledge}

The terms professionalism and professionalization are social constructs (Gitlin \& Labaree, 1996). They are useful, nonetheless, to distinguish between two unique, though interrelated, processes. Englund (1996) defines professionalism in education as the "internal quality of teaching" (p. 77). Included in this category are requisite traits and functions of teachers. Quality of teaching and professional development would fall into this category. Professionalization, on the other hand, embodies the sociological and historical process "relating to the authority and status of the [teaching] profession" ( $p$. 76). How an occupational group is viewed by the general public determines, in part, the group's level of professionalization.

An important factor intrinsic to the advancement toward both professionalism and professionalization is working conditions. We take for granted adequate working conditions and remuneration when discussing the traditional professions. It is assumed that the status conferred on physicians and lawyers precludes any doubt about adequate compensation for the work that is performed. In fact, professional work is not thought of as a job as much as it is a calling. However, working conditions bear as much importance for ESL teachers as issues of professionalism. Therefore, the association of professional standing with appropriate material conditions adds another dimension to the discussion of professionalization. In fact, there seems to be a cycle of interaction between the three elements; poor working conditions and low pay hinder good professionalism, which in turn hinders the professionalization process, and as a result a lack of professional status prevents the procurement of good material benefits. The cycle repeats from here. Viewed in this way, it appears unreasonable to expect teachers simply to start becoming professional when outside forces determine their positions. Perhaps there is a better place to start.

In order to understand how professionalism affects and is affected by the status and working conditions of teachers via professionalization, it is helpful to find out just what we mean by the term profession. Several traits have 
been observed by sociologists as being integral to this social phenomenon. Freeman (1992) informs us of three essential defining features. "Sociologists who study professions," he states, "point to three critical elements: professions are administered by their members; they have clear standards and processes for entry and licensure; and they operate from a recognized and defined knowledge base" (p. 2). The final element seems to be the most basic to establishing a profession. Who we are is what we know. Therefore, Freeman asserts that it is imperative for the ESL teaching community to define the parameters of its professional knowledge. The next questions, then, are how to define what we know and how to have our knowledge validated.

Larson (1990) claims that "the general structural area to which professional phenomena are attached includes the production of knowledge, as an essential component of the activity of experts" (p. 25). She also states that expert knowledge is historically acquired and produced through the university. The university, in a sense, is entrusted as the keeper of professional knowledge. There are both practical and economic reasons for this.

The first, as Freeman implies above, is to provide a space where understanding of the practice can be promoted. This moves the profession toward excellence and gives it a socially recognized form. It has been documented that teaching in general lacks a well-defined skill base (Lortie, 1975), and there have been recent efforts to bring education, including ESL, into line with other university-based disciplines. Some argue, as Labaree (1992) points out, that the professionalization of teaching can best happen if it mimics the "university-centered and research-based movement" (p. 125) exemplified by medicine.

Those who promote more holistic understandings of education have rejected this notion of a "science of teaching" as not properly suited to the nature of teaching and learning. In second-language education, for example, Freeman and Johnson (1998) argue that the "process-product" approach to research "creates an abstract, decontextualized body of knowledge that denies the complexities of human interaction and reduces teaching to a quantifiable set of behaviors" (p. 399). Others have embarked on research based on stories of teachers' experiences in the classroom (Johnson \& Golombek, 2002) in an attempt to earn credibility for the practice-based knowledge that teachers specialize in. All of these efforts are in the interests of improving professionalism in the field, which should, by extension, promote the professionalization of teaching. As stated above, defining our knowledge base as expert is essential to defining our work as professional. It follows that documenting what we do in the classroom and adding it to the academic discourse should raise the status of teachers' work. 


\section{Professionalization and Exclusion}

There is another reason for placing TESL knowledge into the domain of the university: it provides a well-established mechanism of exclusion. It seems unlike language teachers to promote exclusion, but it might be in our best interests to do so in this circumstance. The purpose of defining the knowledge base of a profession is partly to separate out the knowers from the non-knowers. Returning to Freeman's (1992) call for "standards and processes for entry and licensure" as a means to pulling ESL teaching out of the job category and transforming it into profession, it is evident that there must be control over who can practice and who cannot. This is another indispensable aspect of professionalization, and it is closely connected with the project of coming to understand what we know and do as teachers.

Larson (1990) discusses this particular aspect of professional knowledge extensively. A system must be in place by which a professional group can be distinguished from lay people. At the same time, the laity must be familiar enough with the terms of the specialized knowledge to recognize it as such. This is the purpose of certification and the granting of titles. "Certification, which is a centralized mechanism of professionalization projects, requires a basis of homogenized and standardized knowledge" (p. 31). Hence the role of the university is to manage and control access to this specialized knowledge.

One of the most commonly reported complaints in surveys of Englishlanguage teachers has been the negative effect on professionalism of hiring underqualified instructors (Blaber \& Tobash, 1989; Brown, 1992; Freeman, 1992; Wright, 1988). ESL teachers have repeatedly asserted that nativespeaker status is not enough to qualify one as a teacher. In relation to professionalism, the benefits of preventing unqualified people from entering the classroom are clear. With inexperienced and untrained teachers in the classroom, the quality of education suffers. The whole notion that ESL instruction is not only a skill but also a discipline is undermined. As a result, it becomes even more difficult to make the case that TESL is a professional occupation.

The value of professional certification, particularly among the elite professional groups, is not only in guaranteeing quality of service (what we refer to as professionalism), but also in creating conditions of scarcity with economic implications (as relates to professionalization). The university limits access to knowledge, and those who are privileged enough to gain access are rewarded. According to Larson (1990), knowledge becomes an asset that is ultimately converted into status and material success. She writes, "professionalization ... results in translating one order of scarce resources (expertise created through standardized testing at the higher levels of formal education) into another (market opportunities, work privileges, social status or bureaucratic rank)" (p. 30). Thus one argument for professionalization of 
language teachers is that it will bring with it higher standards of pay, benefits, and working conditions. The standards that limit access, and thus create scarcity, are necessary for maintaining a high value on the goods inherent in the profession.

In contrast to this, however, teaching in general has a history of easy entry. Lortie (1975) documented and discussed this phenomenon in detail in his extensive book on the sociology of teaching, Schoolteacher. In this work, he described teaching as a semi-profession and attributed this partly to the characteristic ease with which people can embark on a teaching career. He writes,

society, it seems, has preferred to get teachers by easing access rather than by offering higher rewards; thus, while other fields seeking professional recognition have been able to raise entry standards ... the educational qualifications required of teachers have simply kept pace with general trends. (pp. 23-24)

The hiring practices in ESL that have raised concerns with teachers erroneously place an emphasis on English-speaking skills as a baseline qualification for teaching the English language. Hence compared with general education, TESL demonstrates an even lower standard of admittance. Johnston (1997) observes that TESL and TEFL are "permeable" careers with extremely high rates of attrition (p. 698). With such high numbers entering and leaving the occupation, it becomes difficult to demand high standards of certification. As a result, the profession maintains its low status and consequent inferior rewards.

The professionalization process remains stunted largely because market forces rather than a governing body control standards of hiring. Gitlin and Labaree (1996) write,

What tends to be the contested terrain of professionalization ... is ... the criteria by which groups make claims about their knowledge, abilities, and skills. One factor that affects the success or failure of a professionalization project is the extent to which members of an occupational group can restrict access to their ranks. That is, an aspiring profession must corner the market for a particular service. This monopoly both raises the status of the service givers, because of their membership in an exclusive organization, and enhances their value in the occupational market-place, because of artificial scarcity. (pp. 89-90)

Unfortunately for ESL teachers, we do not control who may or may not teach English. To a large extent, it is the business sector that determines who may engage in the teaching of English.

In Vancouver, for example, newspapers have recently given attention to the contribution of ESL schools to the local economy. As of November 2003, 
an estimated 170 language schools were operating in the area (Bellett, 2003). At this time, there seems to be no supervisory body with the power to authorize whom these schools hire to do the job of teaching. To add to the concern about the quality of education offered by these institutions, current plans to deregulate private institutions in the province further hinder the efforts to professionalize teachers who work in these contexts. One former administrator of a private college in Vancouver stated his concern over recent changes:

The new PCTIA [a government mandated body] will be dominated by business-oriented schools that are more interested in profits than in offering high-quality academic programs. "They rush their clients through," he said. "I use the word clients because that's what the industry uses. They rush through as many as they can to make money, unfortunately. Unfortunately for the student." MacLeod, 2004)

And, I might add, for the teacher.

One point must be addressed here regarding standards and certification. TESL Canada has developed a hierarchy of certification based on several criteria including university education, TESL training, experience in the field, and performance reviews (TESL Canada, 2004). As a means to prevent unqualified people from teaching ESL in Canada, however, it falls short. There are no methods of enforcing these standards. Schools may choose to hire according to the TESL Canada criteria or, as described above, they may simply hire according to the bottom line. Lower standards translate into lower pay.

\section{Structures that Support Professionalization: The University}

In order to professionalize, then, should we be pushing for greater control of our knowledge by the university? Should we take the power of determining who may or may not teach out of the free market and put it into academy? The university, after all, purports to maintain a disinterested approach to the protection of knowledge, sheltering it from materialistic influences. To follow the traditional approach to professionalization would be to sanction academic regulation of what and how we teach.

Some serious problems, however, have been observed for language teachers in the university context. The struggle outlined above to have language teaching recognized as a discipline rather than a trade indicates a strong resistance to its place among the disciplines. Education in general, and ESL specifically, have never experienced the status enjoyed by better-established disciplines (see Yeager-Woodhouse, 2003, for empirical evidence on this). One source of their low status has been attributed to the fact that ESL teaching is seen as remedial work. Studying the English language is not seen as a value unto itself; rather, it is viewed as a means to acquiring more 
"worthwhile" knowledge or skills, particularly those that lead to jobs (Auerbach, 1991). Another explanation has been that professors of education who invest their time in teacher-training are unable to produce research in the same way or at the same rate as other disciplines (Labaree, 1992). The result has been devastating for some faculty members in language education. Yeager-Woodhouse (2003) observes that a reduced rate of publication has made it difficult for some language teacher trainers to gain tenure. Other sources of the lack of status may be the relegation of teacher knowledge to the ranks of "practical" in a general discourse that values the abstract.

These possibilities can be better analyzed by fitting them into a paradigm that looks more closely at control of knowledge. Larson's (1990) central aim is to reveal the dynamics that are in place in the construction of expert knowledge. She draws from Foucault in examining the relationship between power and discourse. There is a great distance between the "core" of knowledge and its periphery. The center is created and controlled by those with the power to define what constitutes valid knowledge.

Discourse in professions ... are [sic] organized around "practical" core regions ... but where the attempt to give such professions the legitimacy of a "scientific" (or at least a dispassionate) claim to truth has been made, the institutional advancement of such claims has also been normally located in the university system. (p. 38)

She continues, "For average practitioners, the core is a distant area indeed. They are confronted with a multitude of 'truths,' and their claim to being possessors of true discourse must be renegotiated in the different instances of their practice" (p. 39). Control of the discourse, then, is at the core where it is decided who may have access and under what conditions. This paradigm clearly delineates the elitism inherent in academia and in professions. If we are to buy into traditional notions of professionalization, then we are accepting an elitist model.

A tension exists in our profession. On the one hand, we desire to have our practice validated as a profession by the university. This was the call made by Lortie (1975) over 30 years ago for mainstream education. Teaching is too limited to the classroom and practical knowledge, he argued. "Few teachers," he observed, "connect their knowledge of scientific method with practical teaching matters ... Students should be pressed to forge more connections between theory and practice" (p. 231). Since Schoolteacher was published, mainstream education has undergone extensive standardization involving legitimization of its knowledge in academe.

On the other hand, we resist the abstraction of knowledge typical of academic discourse in that it invalidates what we do in the classroom. Labaree (1992), for example, rejects the notion that mandating graduate-level qualifications will improve the quality of instruction in mainstream teaching. 
His concern is that "emphasizing the specialized expertise of teachers ... will undermine democratic control of schools" (p. 148). In the core versus periphery concept of expertise, teachers' increased attachment to the core in turn marginalizes others in the educative process, namely, students and parents.

Others, as mentioned above, call for more focus on teachers' experiences as a source of theory (Freeman \& Johnson, 1998; Freeman \& Richards, 1996; Goodson \& Hargreaves, 1996; Johnson \& Golombek, 2002). The margins need to be brought into the central discourse. In this sense, defining our knowledge base is a political project as mentioned explicitly by Freeman and Johnson. To change the nature of the core, to de-authorize it, is to do battle with the very structure of the institution whose approval we seek. This perhaps accounts, at least in part, for the devaluation of education as a discipline. It certainly guarantees that language education will continue to be relegated to the margins of academia.

Further to this, if we are genuinely to record the practices of teachers of ESL, then we run the risk of exposing inexpert practice. As mentioned above, the diversity of backgrounds of various people who teach English may include low levels of certification. This has been the result of non-standardized hiring practices. To include among our knowledge base that which would ideally be excluded threatens the integrity of our profession. Consequently, we jeopardize even further our standing in the university. However, this has been the explicit solicitation from Freeman and Johnson (1998) who ask that we "acknowledg[e] existing practices, in all of their less-thandesirable aspects, and try ... to understand why those practices happen as they do" (p. 410).

The implication here is that if we are able to uncover what happens in the classroom, then we will be able to take a more realistic approach to decisions about how to train teachers. In view of the current discussion, it will also allow us to approach the problem of professionalization from evidence grounded in real teachers' real lives. From here we can discuss whether we should move forward by enforcing standardized certification or if perhaps we need to look at other approaches.

\section{Finding Out Who We Are}

Experience-based research that investigates the conditions of language teachers' working lives is scarce. However, the few data that do exist hint at a much larger story. Descriptions of teachers' lives indicate that the context in which teachers work has a huge effect on their professionalism, and consequently the professionalization of the whole group.

Two studies are particularly striking in how they tie teacher learning and professionalism to the conditions of their work. Johnston (1997), in his life history research with EFL teachers in Poland, discovers that the group of teachers he interviews lack distinct teacher career stories and thus a profes- 
sional identity. He learns that teachers are unable to commit to the profession because they are overworked and cannot continue to sustain themselves through the work they do. "You have to have another means of support to be able to afford to do such charity work, because that's virtually what it is" ( $p$. 704 ) is how one teacher in the study puts it. Further investigation reveals that these types of problems are not limited to language teachers in Poland.

On the issue of professionalism, this study sheds light on the claim by some (Edstam, 2002) that increased professional development on the part of the teacher will uplift the job of English-language teaching into the domain of the professions. Another instructor responded to the notion of being a professional this way:

I don't have time to organize my classes in such a way that they would look like, as if, well, they are organized by a professional person ... But I'm not going to do more because first of all I don't have time, and secondly it's not paid enough to work more, I think; and then I'm not going to do something, as I said I'm not an altruist, and it's a cheat-off, actually, what we're doing, with the, well, the Ministry of Education, and what's going on in this country. (Johnston, 1997, p. 705)

This speaker articulates the strong connection between her professional behavior (or lack thereof) and the sociopolitical context in which she operates. Johnston makes a claim for the need for further research to determine if this is unique to the Polish context and to determine what changes to the currently poor working conditions might benefit the profession. He reasons that the problem is not due to a lack of effort on the part of the individual teachers, but rather "broader contextual" reasons (p. 703).

Similarly, Crookes and Arakaki (1999) find that it is the job situation rather than a lack of professionalism that prevents some teachers from excelling at their work. The researchers set out to discover "whether the academic journal is successful in communicating research findings to teachers in a form they can use" (p. 15). They learn that their question is unanswerable because the teachers do not have the luxury of time to read professional articles. This study clearly emphasizes the distance between academia (the core) and the reality of those working in the field. It is not simply because teachers are unmotivated or unqualified. As in the above study, these teachers simply do not have the freedom to put time into professional development. For example, one of the teachers confessed,

I'm very frustrated. I was feeling bad when I was running around three schools. I knew I wasn't as good as I could be ... So it doesn't give you much time ... when you're talking about reading journals and going to conventions. For some people that's a joke. Who has the time? (p. 17) 
Unexpectedly, the researchers were forced to acknowledge that the time and effort teachers put into teaching and preparation was severely limited by the their employment situations.

Both studies underscore the attention that needs to be given to the sociopolitical contexts of teaching. Specifically, the economic conditions in which many teachers are entrenched limit their abilities to do well at their jobs. These conditions certainly prohibit any program of professionalization that the larger occupational group might undertake. As Auerbach (1991) states, "we are workers in a system that doesn't value our work, and we need to act like workers" (p. 7). Perhaps the more mundane aspects of our careers need to be considered. This is one side of the professionalization puzzle, and although some believe that,

until the field of TESOL is viewed as a profession with unique characteristics and ... until TESOL professionals are viewed as having comparable worth to peers and colleagues, it will be difficult to resolve or even address many salary, security, and benefit issues (Blaber \& Tobash, 1989 , p. 4),

the evidence shows that improvement of working conditions might well be as good a place to start as professional development and external recognition.

\section{Structures that Support Professionalization:}

The Professional Association

To summarize some initial points, professionalism and professionalization are distinct but contingent processes. It is impossible to argue, however, that the professional status of an individual or group of teachers can be raised simply by an increase in professional development or in the recording of our professional knowledge. Therefore, although reflection on one's practice may currently be at the center of many professional development movements, it cannot stand alone. Some account must be made for the external conditions that constrain teachers from performing well. These external constraints are an undeniable limit to professionalization.

Professionalization is an historical process (Friedson, 1994; Larson, 1977) that cannot be isolated from the social and economic context of the occupational group. Teachers of English as a second language have their own unique history beginning, according to one account, in the early to middle part of the last century (Wright, 1988). We are still a fledgling group. Some argue that this gives us the advantage of being able to help determine the shape our profession will take (Wright). However, as Larson (1990) warns, we must be aware that the notion of a profession is not a stable category to be applied to a group without critical redefinition. Rather, it is a "complex 
programme of research" (p. 44) that we are in the position as early participants to undertake.

It is necessary to find community support to improve our professional standing. As mentioned above, it is typical for professions to be attached to the university where ideas can be developed toward a greater understanding of the practice. The university also acts to limit who can obtain the knowledge intrinsic to the discipline that, once obtained, endows the practitioner with special privileges and status. It is questionable whether ESL teaching can be considered a profession on these grounds, as the ongoing practice of hiring non-initiates undermines the quality of the practice as a whole and equalizes access to the goods of the profession. In fact, the call for equal access to knowledge runs counter to the hierarchical nature of the traditional professions as well as the university.

Do we as practitioners with our diverse backgrounds want the university to be the keeper of our knowledge and the gateway to our profession? In view of the evidence that tells us the university system does not always value our epistemology, perhaps there are other solutions.

In this article I discuss two of the conditions laid out by Freeman (1992) that are characteristic of professions. The first point that was elaborated is a need for a distinct body of knowledge; the second is a system of certification to establish standards of entry into the occupation; the third is that "professions are administered by their members" (p. 2). Having a strong and wellorganized professional organization to represent the occupational group is essential. Like the university, or in association with the university, a formalized professional organization can limit entry to the profession.

This seems to be a primary endeavor of TESL Canada (2004), which has recently established a set of national standards based on a hierarchy of qualifications. The organization hopes to "promote excellence in the teaching and learning of English as a Second Language ... by promoting professional certification standards that are recognized in all provinces." TESL claims that one advantage to the teacher is "programs that hire qualified professionals will attract more students." This might be true; however, it leads to other concerns. One is that it reinforces a consumer-driven model of education in which the student is the "client." At the same time, although it might encourage higher standards, it does not enforce them.

The only way to mandate standards is through the power of the state, as is the case with provincial teacher organizations such as the British Columbia College of Teachers (BCCT). The BCCT follows the Teaching Profession Act, which gives schoolteachers the power and responsibility to regulate themselves. Because government lacks "detailed theoretical knowledge as well as experience within the profession ... government accountability is therefore transferred to the self-regulating profession" (BC College of Teachers, 2004). Teachers cannot teach grade school or high school in BC without first becom- 
ing members of the BCCT, and in order to become members of the BCCT, teachers must meet certain criteria. In this way, the profession is regulated both through the universities that conduct the training and, ultimately, through acceptance into the professional body. Without a similar authority, TESL Canada and its affiliate associations are limited in their power to impose standards.

TESL Canada and its affiliates also strive toward excellence by creating opportunities for development in the profession through conferences, scholarships, and the publication of an academic journal. In other words, the focus is on the creation of a professional discourse. However, we must question who controls this discourse. Although I am not familiar with any studies that have examined the demographics of those teaching ESL as compared with those speaking for the profession, certain reports that claim to represent the voices from the field seem suspicious. For example, in an article reporting an employment concerns survey for members of TESOL, ${ }^{2}$ Blaber and Tobash (1989) relate that of 523 people surveyed, $66 \%$ have master's degrees, $20 \%$ have doctorates and that $44 \%$ of respondents are employed by four-year colleges or universities. Keeping in mind that the respondents are only those who are already members of TESOL, one wonders how representative this is of the members of the profession in general.

Another interesting point emerges from this report. Blaber and Tobash (1989) write,

it is striking that $73 \%$ of the respondents indicate that they are employed full-time and that $44 \%$ work in 4 -year colleges / universities. It is well-documented that more higher education part-timers are employed at 2-year institutions, and survey respondents fit this pattern: of those primarily employed at two year colleges, the percentage of parttimers was twice that of full-timers. But the fact that part-timers constitute only $27 \%$ of respondents raises several questions. Is a higher percentage of the TESOL membership indeed employed full-time? Or, do full-timers at 4-year institutions complete surveys? (p. 4)

This is an important question. Perhaps more studies such as those by Johnston (1997) and Crookes and Arakaki (1999) that describe the working conditions of teachers will lead us to the answer as to why some teachers have time to fill out surveys, whereas for others it is an unaffordable luxury.

The results of this survey also lead to another criticism of professional organizations. Instead of providing an alternative structure to the university, these groups seem to be represented by teachers closely aligned with the university. This is illustrated by the credentials represented in the abovementioned survey, which does not depict a true picture of those working in the field. In addition, a browse through one of the professional journals 
shows that the dominant voice comes from those accredited by the university. Institutions commonly replicate social hierarchies; similarly, the professional organization has a tendency to mimic how discourse is structured in the university. The workers who do the job of teaching exist on the periphery of the system. The most highly valued knowledge, considered in the dominant discourse to be closer to the "truth," dwells in the center protected by those whose knowledge is endorsed by the university.

It is possible for the professional organization to take a different direction. One aspect of professionalization not yet fully examined is the working conditions and salaries of teachers. The BCCT clarifies that it is not an advocacy group. It does not act to advance "the financial and working conditions for individual members of the profession" (BC College of Teachers, 2004). This is the job of the BC Teachers' Federation (BCTF). ${ }^{3}$ TESOL endeavors to attend to both aspects of professionalization by setting standards for teacher qualification as well as participating to a certain extent in advocacy on behalf of the membership. For example, TESOL administered a position statement in March 2003 for equitable treatment of part-timers (TESOL, 2003).

BC TEAL, the BC affiliate of TESL Canada, also purports to "advance the profession ... through professional development, promotion of standards, advocacy and representation of ESL professionals" (BC TEAL, 2004, italics added). Despite this claim, it remains unclear exactly how BC TEAL achieves the latter. This would require a political struggle with employers in the ESL industry and / or with government to demand baseline working conditions for all practitioners. This is a task usually assigned to a trade union. The starting point for TEAL, however, might be to learn from the people it represents how they might best be supported.

\section{Some Questions as Conclusions}

Perhaps what we are exercising is exclusion by ignorance. Perhaps at some level, we do not want to admit that our work force includes those without proper training, those who are hired by private institutions and paid a pittance, and those whose workloads prohibit them from participating in professional organizations and attending conferences. However, the occupation is composed of these individuals, so acknowledging and trying to understand the variety of contexts people work in seems to be a more productive beginning to promoting professionalization than, in Larson's (1990) words, "retrench[ing] behind the boundaries of ... discursive fields and retreat[ing] towards the protected core" (p. 45).

This article is intended to raise questions and suggest possible sources of answers. I hope it conveys the rich possibilities for inquiry in the everyday life of ESL teachers. We should be taking each member of the profession into account. We need to find out who we are. As Shrier (1993) asserts regarding 
foreign language teaching, "the voice that teaches world languages should be the voice that is most listened to and esteemed" (p. 120). We need more descriptive accounts of teachers' experiences that consider the relationship between issues of professionalism and of social and economic standing. We sometimes need to look beyond individual internal development to conditions external to the teacher. In order to do this, we need to seek out teachers in all contexts, particularly those on the fringes.

Working conditions do not necessarily improve through increased professional status; they are a starting point unto themselves. In view of this, we may need to consider what supporting body would best be suited to addressing our profession as a community of workers. Auerbach (1991) would claim that this is the role of collective bargaining. The BC Medical Association and the BC Bar Association provide similar types of support. A study of unionized ESL teachers might provide some clues as to the effectiveness of unions in raising the professional status of ESL teachers.

The representative body of the profession must also be ready to acknowledge its shortcomings and prepared to distribute power more evenly in the interests of compassion, as well as in the interests of professionalization, for "when power is unevenly distributed, it can ... block change and development" (Englund, 1996, p. 77). We need repeatedly to ask the questions: Who speaks? Whose knowledge counts? Who controls the discourse? As a group we can decide who is included and who is not. Perhaps this is a decision that must be made in order to protect the integrity of the profession, but it must be made with full awareness of the parameters of the occupational group.

We must admit to ourselves that when it comes to control of knowledge, that control is political power. The process of professsionalization is by its nature a political process. This process may even be messy at times. In order to gain greater recognition of teacher knowledge in the university, perhaps it is not we, but the university that must change. In addition, we must challenge market forces that weaken the more noble aims of our work in the interests of profit. In doing this, we must admit that at some point only the power of the state can give us the security we seek. Only as a group will we be able to communicate loudly enough that political bodies can hear us.

So am I in or out? Do I count as a professional? One choice might be to simply draw the line in the grey area of the margins and say, "You're in, but sorry, you're out." Thus the lowest of the low would be deemed "nonprofessional" and those in the center, could take comfort that their status will be protected and even promoted. But I wonder if this is true to the nature of people whose job it is to try to help their learners feel safe and included. Thus before we decide who we are not, we need to learn about who we are. The profession must account for all of its members in order to grow. 


\section{Notes}

${ }^{1} \mathrm{EFL}$ is to be be assumed when ESL is used.

${ }^{2}$ The professional organization Teachers of English to Speakers of Other Languages

${ }^{3}$ It is interesting to note that the BCTF is 70 years older than the BCCT, which is the reverse situation of many professions such as law, medicine, and nursing (BC College of Teachers, 2004).

\section{The Author}

Sherry Breshears has taught English in Pakistan, Korea, and Thailand. She has been teaching at Pacific Gateway International College in Vancouver for more than six years. Currently, she is completing a Master of Arts degree at Simon Fraser University with a focus on the working conditions of teachers in the private ESL industry.

\section{References}

Auerbach, E.R. (1991). Politics, pedagogy, and professionalism: Challenging marginalization in ESL. College ESL, 1(1), 1-9.

Bellet, G. (2003, November 7). "Little-understood" ESL schools chalk up 760M for economy. Vancouver Sun, p. G3.

Blaber, M., \& Tobash, L. (1989). Report of employment concerns survey. TESOL Newsletter, $23(2), 4-5$.

Brown, J. (1992). The biggest problems TESOL members see facing ESL/EFL teachers today. TESOL Matters, 2(2), 1,5.

BC College of Teachers. (2004). Understanding our profession. Retrieved July 15, 2004, from http://bcct.ca/profession.html

BC TEAL. (2004, May 31). BC TEAL mission statement. Retrieved July 15, 2004, from http://www.bcteal.org/

Crookes, G., \& Arakaki, L. (1999). Teaching idea sources and work in an ESL program. TESOL Journal $8(1), 15-19$.

Edstam, T. (2001, July/August). Putting the "pro" into TESL/TEFL professionalism. ESL Magazine, 4(4), pp. 16-18.

Englund, T. (1996). Are professional teachers a good thing? In I.F. Goodson \& A. Hargreaves (Eds.), Teachers' professional lives (pp. 75-87). London: Falmer Press.

Freeman, D. (1992). What is a burning issue in the profession today? TESOL Matters, 2(2), 4.

Freeman, D., \& Johnson, K. (1998). Reconceptualizing the knowledge-base of language teacher education. TESOL Quarterly. 32, 397-417.

Freeman, D., \& Richards, J. C. (Eds.). (1996). Teacher learning in language teaching. Cambridge, UK: Cambridge University Press.

Friedson, E. (1994). Professionalism reborn: Theory, prophecy, and policy. Cambridge, UK: Polity Press.

Gitlin, A., \& Labaree, D.F. (1996). Historical notes on the barriers to the professionalization of American teachers: The influence of markets and patriarchy. In I.F. Goodson \& A. Hargreaves (Eds.), Teachers' professional lives (pp. 88-108). London: Falmer Press.

Goodson, I.F., \& Hargreaves, A. (Eds.). (1996). Teachers' professional lives. London: Falmer Press.

Johnson, K.E., \& Golombek, P.R. (Eds.). (2002). Teachers' narrative inquiry. Cambridge, UK: Cambridge University Press.

Johnston, B. (1997). Do EFL teachers have careers? TESOL Quarterly, 31, 681-712.

Labaree, D. (1992). Power, knowledge, and the rationalization of teaching. Harvard Educational Review, 62, 123-154.

Larson, M.S. (1977). The rise of professionalism: A sociological analysis (pp. 24-50). Berkeley, CA: University of California Press. 
Larson, M.S. (1990). In the matter of experts and professionals, or how impossible it is to leave nothing unsaid. In R. Torstendahl \& M. Burrage (Eds.), The formation of professions: Knowledge, state and strategy. London: Sage.

Lortie, D.C. (1975). Schoolteacher: A sociological study. Chicago, IL: University of Chicago Press.

MacLeod, A. (2004, February 19-24). Trying to keep public eye on private education. Georgia Straight, pp. 27, 29.

Pennington, M. (1991). Work satisfaction and the ESL profession. Language, Culture, and Curriculum, 4(1), 59-86.

Shrier, L.L. (1993). Prospects for the professionalization of foreign language teaching. In G. Guntermann (Ed.), Developing language teachers for a changing world (pp. 105-123). Lincolnwood, IL: National Textbook Company.

TESL Canada. (2004, January). National professional certification standards for instructors of English as a Second or Foreign Language in adult programs. Retrieved July 15, 2004, from http://www.tesl.ca

TESOL. (2003, March). TESOL position paper on equitable treatment for part-time, adjunct, and contingent faculty. Retrieved July 15, 2004, from http://www2.tesol.org/assoc/statements/2003-ptequity.html

Torstendahl, R., \& Burrage, M. (1990). The formation of professions: Knowledge, state and strategy. London: Sage.

Wright, S. (1998). TESOL. Our evolving profession. TESOL Neusletter, 22(5), 23, 29.

Yeager-Woodhouse, D. (2003, November 15). Sustaining their lives: A life history study of ESL teacher educators. Paper presented at the TESL Canada/BC TEAL conference Connecting Communities: Inspirations and Aspirations, Vancouver. 